\title{
80. Land Deformations on the Western Littoral of Sikoku.
}

By Akitune Imamura and Naomi Mryabe.

(Comm. by A. Imamura, M.I.A., July 13, 1942.)

In the course of study of secular variations in the heights of the yearly mean sea-levels at various mareograph stations, it was noticed that. the mean sea-level at Uwazima, a city on the western coast of Sikoku, underwent a remarkable fall and rise in some ten year period, that is to say, a rise of about $70 \mathrm{~cm}$ during the period from 1927 to 1931 and a fall of about $50 \mathrm{~cm}$ during the ensuing years down to 1937 $\left(\right.$ Fig. 1) ${ }^{1)}$. This remarkable fall and rise of the mean sea-level is likely

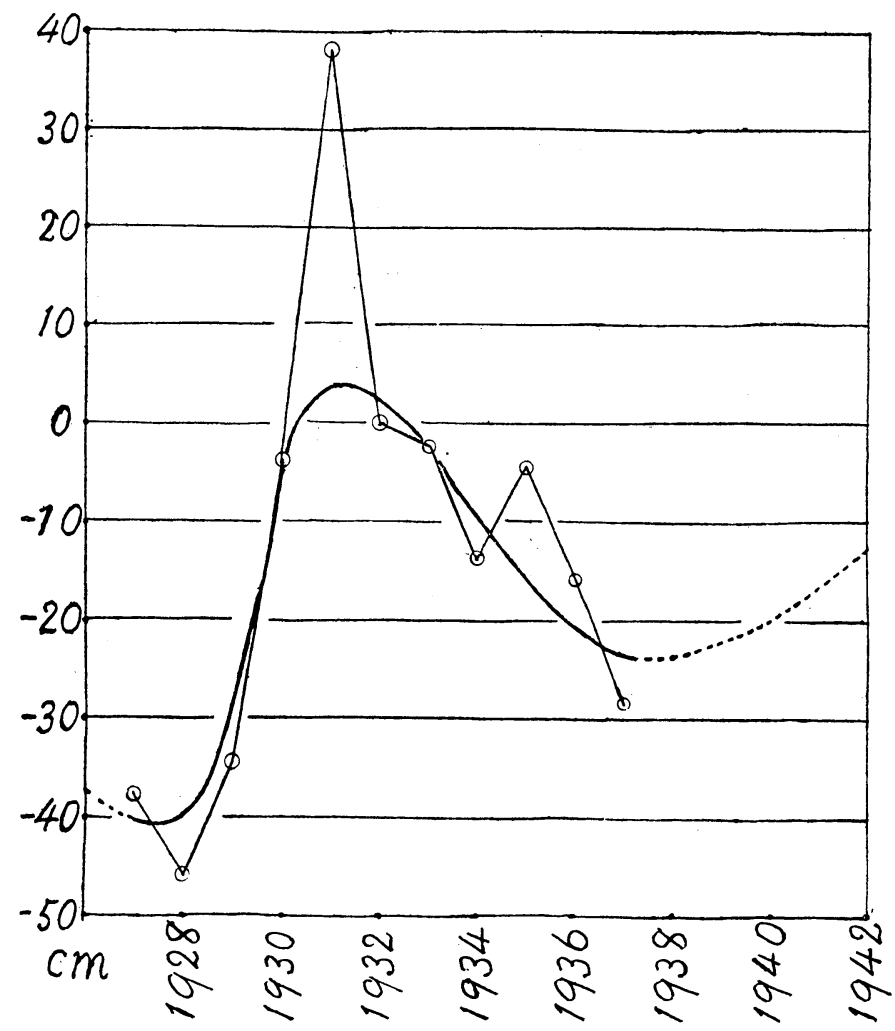

Fig. 1. Variation in the heights of the yearly mean sea-level at Uwazima.

to have been the result of rise and fall of the land itself. Considering that the change, though extraordinarily large, is in no wise extravagant as compared with what was experienced in Beppu Bay, about $80 \mathrm{~km}$ west by north of Uwazima, it became desirable to investigate the

1) N. Miyabe, Earthq. Res. Inst., 19 (1941), 238-247. 
true nature of the phenomenon by the only means left for it, namely, the revision of the line of precise levels.

With the above-mentioned purpose, and through the courtesy of the Military Land Survey, the line of levels, which links Matuyama with Sukumo via Yahatahama and Uwazima, with 87 bench-marks on it, or about $170 \mathrm{~km}$ in length, was rerun in January-February, this year, former survey of levels having been carried out in October-December, 1937, for the section between Matuyama and Hutaiwa near Yahatahama and in May-November, 1932, for the section between Hutaiwa and Sukumo. (See Fig. 2.) The vertical displacements of each benchmark for the intervening period was worked out with reference to B. M. J-3483, which is situated at Matuyama, its height being assumed as unchanged during the said periods.

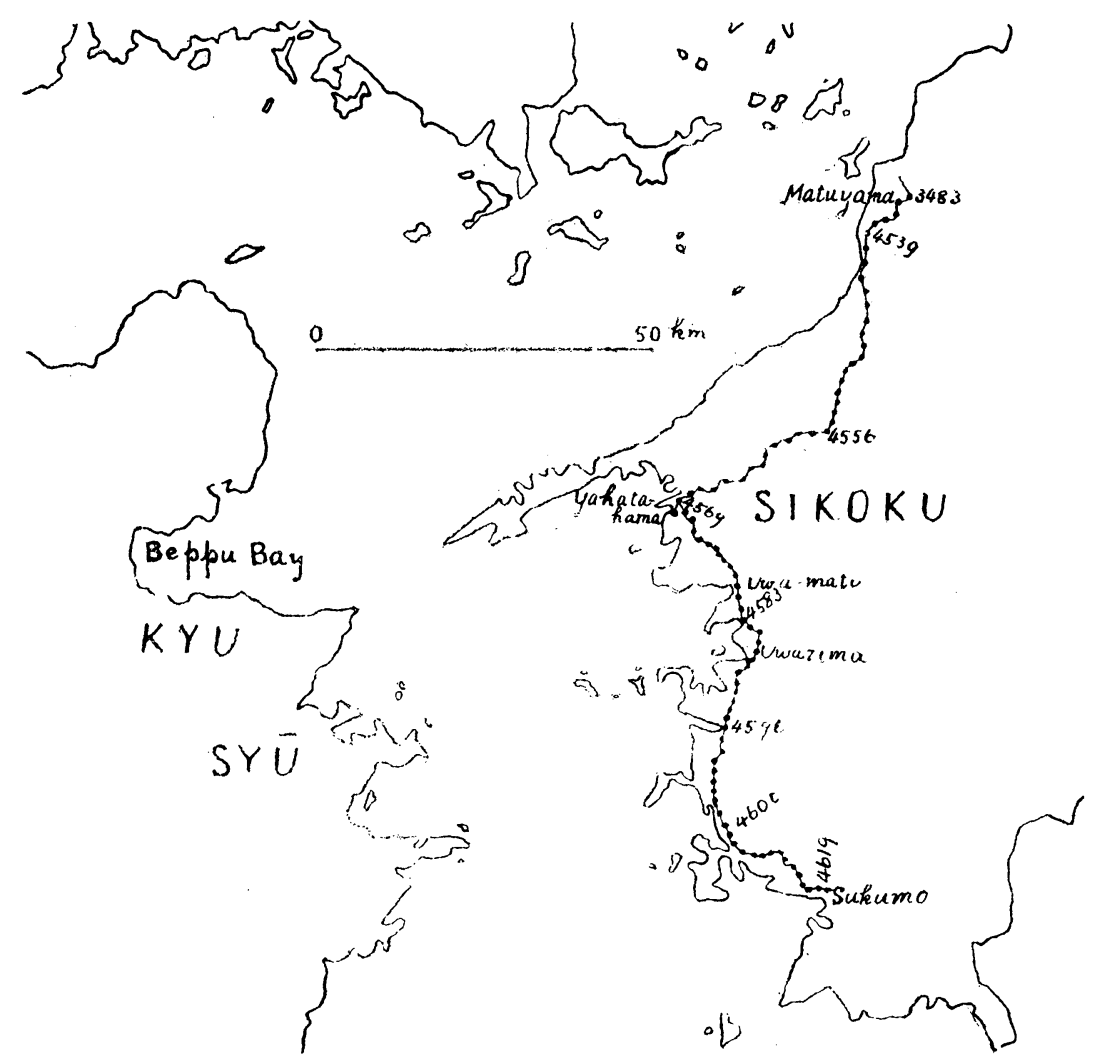

Fig. 2. Line of precise levels linking Matuyama with Sukumo.

The vertical displacements of the bench-marks thus worked out are given in Table 1 and diagrammatically shown in Fig. 3 . It will be seen that bench-marks at Uwazima or near it do not, contrary to our expectation, show any extraordinary displacements assumable from the result of mareograph observation, the change being merely an uplift of as large as $5 \mathrm{~cm}$ as referred to that at Sukumo.

To explain the cause of . this discordance, following assumptions are thought available. 
TABLE 1. Vertical displacements undergone by B.-M. No. 3483-4571 during 1937-1942 and by No. 4571-4619 during 1932-1942.

\begin{tabular}{|c|c|c|c|c|c|c|c|}
\hline $\begin{array}{l}\text { B.-M. } \\
\text { No. }\end{array}$ & $\begin{array}{l}\text { Change } \\
\text { in mm. }\end{array}$ & $\begin{array}{l}\text { B.-M. } \\
\text { No. }\end{array}$ & $\begin{array}{l}\text { Change } \\
\text { in } \mathrm{mm} \text {. }\end{array}$ & $\begin{array}{l}\text { B.-M. } \\
\text { No. }\end{array}$ & $\begin{array}{l}\text { Change } \\
\text { in mm. }\end{array}$ & $\begin{array}{l}\text { B.-M. } \\
\text { No. }\end{array}$ & $\begin{array}{l}\text { Change } \\
\text { in } m m \text {. }\end{array}$ \\
\hline \multicolumn{2}{|c|}{ Matuyama } & 4557 & -25.0 & 4576 & -13.2 & 4597 & -45.0 \\
\hline 3483 & 0.0 & 4558 & -26.2 & 4577 & -14.5 & 4598 & -42.9 \\
\hline 4535 & 4.4 & 4559 & -28.2 & 4578 & -13.7 & 4599 & -43.4 \\
\hline 4536 & $\begin{array}{l}4.4 \\
3.0\end{array}$ & 4560 & -33.2 & 4579 & -20.4 & 4600 & -42.9 \\
\hline 4537 & $\begin{array}{r}3.0 \\
-5.6\end{array}$ & 4561 & -28.2 & 4580 & -12.2 & 4601 & -40.2 \\
\hline 4538 & $\begin{array}{r}-0.0 \\
1.4\end{array}$ & 4562 & -32.9 & 4581 & -20.6 & 4602 & -54.6 \\
\hline 4539 & $\begin{array}{l}1.4 \\
1.4\end{array}$ & 4563 & -35.3 & 4582 & -31.3 & 4603 & -64.9 \\
\hline 4540 & $\begin{array}{r}1.4 \\
-2.9\end{array}$ & 4564 & -33.4 & 4583 & -27.1 & 4604 & -62.7 \\
\hline 4541 & $\begin{array}{l}-2.9 \\
-4.1\end{array}$ & 4565 & -31.8 & .4584 & -28.7 & 4605 & -72.5 \\
\hline 4542 & $\begin{array}{r}4.1 \\
-2.3\end{array}$ & 4566 & -31.0 & 4585 & -29.9 & 4606 & -77.4 \\
\hline 4543 & -6.1 & 4567 & -29.8 & 4586 & -29.7 & 4607 & -67.4 \\
\hline 4544 & -11.4 & 4568 & -27.7 & 4587 & -35.2 & 4608 & -75.0 \\
\hline 4545 & -19.8 & 4009 & -26.7 & 4588 & -42.7 & 4609 & -74.5 \\
\hline 4546 & -18.4 & \multicolumn{2}{|c|}{ Yahatahama } & \multicolumn{2}{|c|}{ Uwazima } & 611 & 6.0 \\
\hline 4547 & -18.0 & & & & & 4612 & -69.6 \\
\hline 4548 & -15.8 & 4571 & 26.2 & & & 4613 & -66.5 \\
\hline 4549 & -16.0 & 4571 & 26.2 & 4589 & -27.7 & 4614 & -66.9 \\
\hline 4550 & -20.8 & \multirow{2}{*}{\multicolumn{2}{|c|}{ Hutaiwa }} & 4590 & -28.9 & 4615 & -57.0 \\
\hline 4551 & -29.0 & & & 4591 & -26.1 & 4616 & -60.6 \\
\hline 4552 & -18.7 & 4571 & -26.2 & 4592 & -24.3 & 4617 & -64.2 \\
\hline 4553 & -24.0 & 4572 & -19.1 & 4593 & -26.8 & 4618 & -65.9 \\
\hline $\begin{array}{l}4554 \\
4555\end{array}$ & $\begin{array}{l}-23.6 \\
-240\end{array}$ & 4573 & $\begin{array}{l}-11.3 \\
-193\end{array}$ & 4594 & -22.4 & 4619 & -84.8 \\
\hline $\begin{array}{l}4000 \\
4556\end{array}$ & $\begin{array}{l}-24.0 \\
-25.3\end{array}$ & 4575 & -14.3 & 4596 & -48.6 & & \\
\hline
\end{tabular}
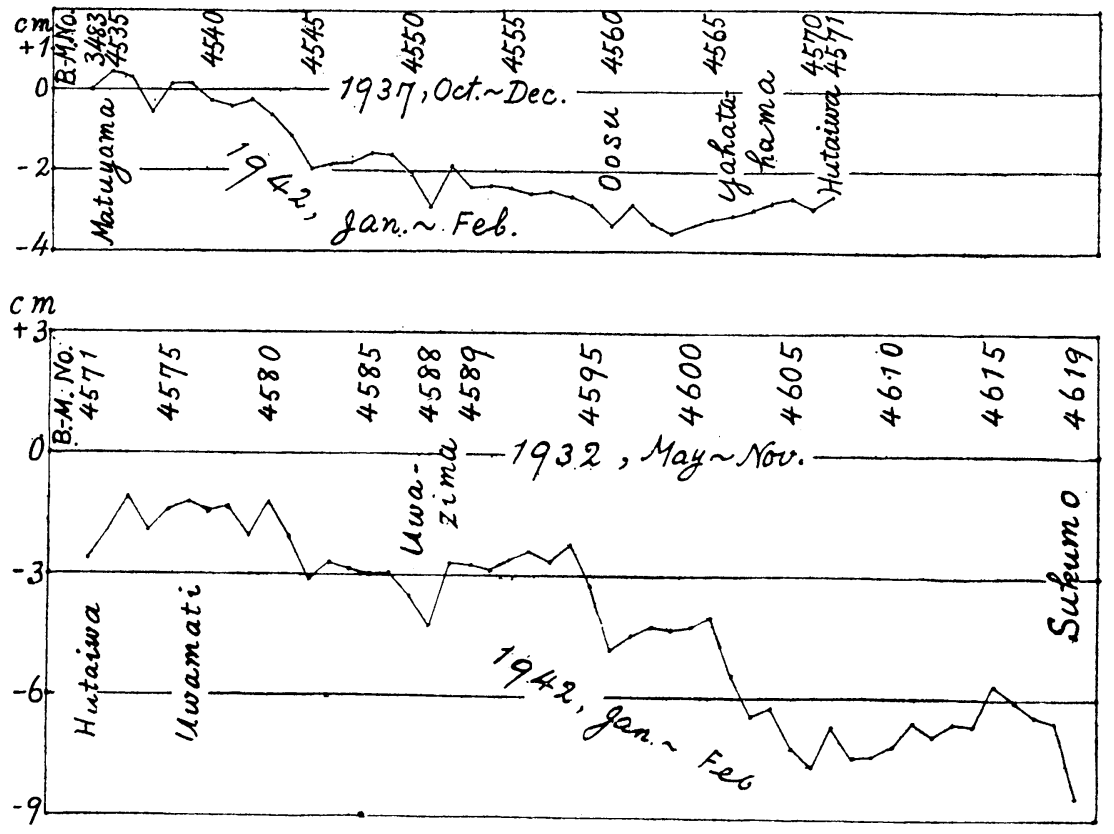

Fig. 3. Change of land level between Matuyama and Sukumo. 
(i) The height of the yearly mean sea-level at Uwazima which had been descending since 1932 turned to rising in 1938, when the height of the sea-level reached minimum.

The change thus supposed is shown in Fig. 1 with a dotted line.

(ii) The observed land deformation was a type of upwarping having its centre towards the north of Uwazima somewhere near Yahatahama. The regions near Matuyama and Sukumo, each about several tens of kilometres respectively to the east or south of the supposed centre, were also within the area affected by this upwarp deformation.

It may be deduced from the above assumptions that the movements of the land at Uwaziwa was directed upwards during 1932-1937, whereas it was directed downwards during 1937-1942, and that the land was as a whole upheaved during 1932-1942. Since the vertical displacements of bench-marks distributed between Matuyama and Yahatahama or Yahatahama and Sukumo are due respectively to the period 1937-1942 or 1932-1942, it may be expected that the land deformation in the region between Sukumo and Yahatahama for the period 19321942 would be of a southward tilting, while that between Yahatahama and Matuyama for the period 1937-1942 would be a westward tilting, though less than the former in amount. Such a tendency in the mode of deformation is actually noticeable on the land deformation worked out from the result of recent levelling.

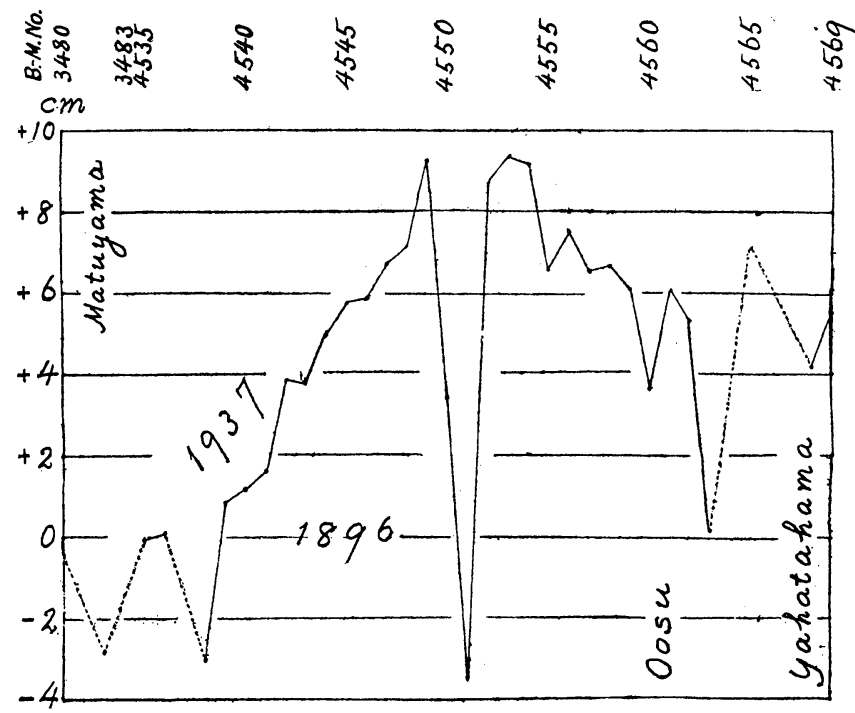

Fig. 4. Change of land level between Matuyama and Yahatahama in the period 1896-1937.

The vertical displacements during the period 1896-1937 of the bench-marks distributed between Yahatahama and Mátuyama are shown for the sake of comparison in Fig. 4, in which is noticed an eastward tilt of the land in the neighbourhood of Matuyama, thus being opposite to that for the period ensuing. This is in fair accord with the view 
that change from fall to rise of the variation in the heights of the yearly mean sea-level at Uwazima is likely to have taken place in 1937 or 1938.

As for the smallness of the relative displacements of the land between Sukumo and Uwazima as compared with the value estimated from the secular variation-in the heights of the mean sea-level, it is notable that the line of level would not traverse the centre of the upwarp deformation. It may therefore be rather natural to consider that the amount of rise of the land near Uwazima relative to that near Sukumo as worked out through relevelling is smaller than that estimated from the observation at Uwazima mareograph station, granted that the station is situated nearer to the centre of the upwarp deformation than the bench-marks.

Needless to say, the present explanation is by no means satisfáctory; it is merely given as a tentative one. In order to obtain a perfect interpretation of the crustal deformation in question, further studies are required to be carried on through revisions of precise levels and mareograph observations for years ensuing.

The present relevelling in the region under consideration was carried out with the aid of a generous grant made us by the Imperial Academy, to whom we wish to express our sincere thanks. 